\title{
The Role of Synchronous Virtual Reference in Teaching and Learning: A Grounded Theory Analysis of Instant Messaging Transcripts
}

\section{Sarah Passonneau and Dan Coffey}

\begin{abstract}
Electronic communication technologies continue to change the landscape of reference services. For many users, virtual communication is the preferred means of conversing. Synchronous virtual reference, similar to other synchronous means of communication, is an important method for reaching students and for providing teaching and learning opportunities. Grounded Theory (GT) research provides a method for examining the transcripts of synchronous virtual reference. In this study, the library implemented the instant messaging (IM) application known as Meebo. Using the qualitative software ATLAS.ti, lowa State University Library researchers uploaded, analyzed, and coded the instant messaging transcripts. From the analysis, a snapshot developed of the library's central role in educating the university community about research resources. This paper describes ongoing challenges that occur during synchronous virtual reference interviews and staff training needs that cannot be captured by number crunching alone. Synchronous virtual reference can provide essential teaching and learning experiences that complement the educational mission of most research universities.
\end{abstract}

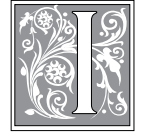

n a New Yorker article published in December 2008, Dana Goodyear discusses a subgenre of fiction emerging in Japankeitai shoshetsu. ${ }^{1}$ Novels in this genre are written by young Japanese women and, notes Goodyear, are autobiographical accounts of the nasty side effects that can come with finding romance. What should be of interest to librarians here is what keitai shoshetsu translates to: "cell phone novel." These novels are written entirely on cell phones. These aren't merely books being read on electronic devices (in many cases the cell phone novels are published in print format); these are novels being written entirely within the frame of text messaging. As librarians, this should be (if we haven't heard it already) the siren that wails, "Offer digital reference service!"

But not all digital reference services are the same. Synchronous virtual reference provides opportunities to dynamically reach students. Some synchronous

Sarah Passonneau is Assistant to the Dean and Assessment Librarian, and Dan Coffey is Languages and Literatures Librarian and Instant Messaging Coordinator, both at Iowa State University Library; e-mail: spassonn@iastate.edu,dcoffey@iastate.edu. 
virtual reference tools are "chat," instant messaging, and text messaging, while e-mail is an asynchronous virtual reference. BBC and British Council define "... online learning, videoconferencing, chat and VOIP [as] synchronous learning tools because the learner and teacher interact in real time," the crucial point being that the participants interact in real time much like writers and readers of keitai shoshetsu. ${ }^{2}$ Synchronous virtual reference works the same way, providing real-time feedback to the user.

The content and service quality of synchronous virtual reference remain an assessment issue. To be effective reference librarians, we must pay close attention to the content of our online or digital dialogues with our patrons. As librarians, are we comfortable and savvy enough with these new technologies to be able to communicate effectively? Does technological ineptitude make us semantically clumsy or unable to provide the level of reference service that we would be capable of in a face-to-face transaction? To date, there have been numerous quantitative studies regarding online reference service, but virtually no qualitative textual studies. A close textual reading of these transactions has not been examined to determine how well we are doing.

At the Iowa State University Library, the assessment librarian and the IM reference coordinator began a qualitative study of archived IM transactions using grounded theory (GT). GT is a qualitative model that analyzes textual data. A researcher implementing GT can holistically examine the content of synchronous virtual reference transcripts. The researchers used the qualitative software ATLAS.ti to review the transcripts to evaluate the "business" that occurs during a synchronous virtual reference interview. As more university administrators ask for data illustrating the relevance of various library services, it is imperative that reference services assess and articulate their central role in assisting student learning. This research demonstrates that synchronous virtual reference dynamically engages users in the research process by providing real-time feedback, which is an important characteristic of authentic learning.

\section{Literature Review \\ Synchronous Virtual Reference}

While library studies addressing the implementation of virtual reference are vast, with at least 50 articles dating back to 1996, when Emory College attempted virtual reference through videoconferencing, it found that there is scant literature dealing with synchronous virtual reference. ${ }^{3}$ The first mention of the term synchronous reference can be found in Joel Cummings's, Lara Cummings's, and Linda Frederiksen's article on virtual reference. $^{4}$

Today, virtual reference includes instant messaging, e-mail, text messaging, or social networking communication. In some cases, such as completely online universities, the only type of reference offered is virtual. ${ }^{5}$ Several studies examine the quantity of different types of virtual reference. Nahyun Kwon, in his study of a national chat reference service, examined the difference between local directional queries and expert reference service. ${ }^{6}$

In 2006, Marie L. Radford conducted qualitative research of 44 chat reference transcripts. ${ }^{7}$ This study emphasized the relational aspects of chat reference, which included deference and closing ritual as elements of building rapport. In this research, rapport is seen as a key element in discerning fluency and effectiveness in the communication between a librarian and user as key elements to a successful reference interview. Ian J. Lee's qualitative and quantitative analysis of chat and e-mail reference addresses technical issues including the speed of communication as well as how delays can hinder the effectiveness of a reference interview to the user. This can lead to disconnects and hang-ups. ${ }^{8}$

These studies implicitly complement a recurring theme in articles dealing with virtual reference and service quality. 
This theme is training. Kathleen Kern, in her book Virtual Reference Best Practices: Tailoring Services to Your Library, details methods for software selection, best practices in staffing, and many other relevant concerns. Faculty training and "buy-in" are of the utmost importance for a successful virtual reference service. Kern's chapter on assessment, while useful, emphasizes service improvement through the examination of the reference staff's ability to answer questions. ${ }^{9}$ Lili Lou provides extensive details concerning the importance of training personnel on chat software, including the pairing-up of librarians to simulate the chat process. ${ }^{10}$ A deeper look at the context and depth of communication is missing, especially in synchronous virtual reference.

\section{Ground Theory}

It is possible that GT as a qualitative analysis can develop a schema for examining and addressing both the relational communication issues touched upon in qualitative research of chat reference. Darlene Weingand provides a broad overview of the GT methodology in the article "Grounded Theory and Qualitative Methodology."11 The most relevant part of Weingand's article details how meaning comes from the researcher's immersion in the data. She writes, "If a certain phenomenon is observed and little information is available concerning why or how it happens then in such a situation, qualitative methods can flesh out what is really happening."12

According to Weingand, there are five research categories that help focus GT for the researcher:

1. Contextual: What is happening?

2. Diagnostic research: Why does it exist or happen?

3. Evaluation research: How well does it happen?

4. Strategic research: What, if anything, should be done about it?

5. Contributions to research theory: Generation of theoretical statements at a certain level about the social world.
This framework proved useful during the analysis of the transcripts.

Pure GT calls upon the researcher to set aside intellectual training. A reflective and thoughtful researcher can develop well-evidenced theories by thorough examination of the data. ${ }^{13}$ For this examination, the researchers attempted to put aside assumptions, with the understanding that their training and experience can never be completely suspended for any type of research.

Four library research articles use GT to examine the searching behaviors of users. Wooseob Jeong examines how cultural background affects Korean students' information-seeking behavior. ${ }^{14}$ Yazdan Mansourian and Tarbiat Moallem looked at users' general approach to Web searching. ${ }^{15}$ The information-seeking patterns of researchers is described by David Ellis. ${ }^{16}$ Margaret Ostrander examines searching behaviors of people using Second Life with exciting results. ${ }^{17}$ These articles proved to be useful examples of GT implementation within the library environment. Unlike Lee's and Radford's research, these articles did not examine virtual reference.

\section{Methodology \\ Overview of Grounded Theory (GT)}

GT is time-consuming methodology that requires revisions, reexaminations, and reassessments before researchers can formulate a theory. ${ }^{18}$ Two researchers, Barney Glaser and Anselm Strauss, are considered the founders of GT. ${ }^{19}$ In the 1960s, Glaser and Strauss were examining individuals' feelings and behaviors regarding death and dying. They felt quantitative models could not sufficiently capture the complexity of the subjects experiences. They developed a qualitative method that allowed them, as researchers, to become immersed in the data. Patterns and ideas develop through immersion. From the patterns a researcher can formulate a theory. Instead of starting with a hypothesis and then proving or disproving it, GT starts with the data and the 
researcher discovers a theory by closely examining it. ${ }^{20}$

Engagement with the data allows the researcher to start developing codes from the materials. Groupings develop from overlapping codes. From groupings emerge patterns or networks. A theory can then be developed from these patterns, or networks, that allows the researcher to generalize their findings to broader issues.

For this study, GT provided a method of examining complete instant messaging transcripts. This methodology provided a framework that facilitates examination of the narrative aspects of synchronous virtual reference. The researchers hoped GT would provide a meta-analysis of this tool. This analysis could provide a framework for other types of qualitative research such as content analysis and ethnographic analysis. Additionally, the researchers hoped that GT would provide a way of describing virtual reference service in a manner that would lead to relevant staff training and awareness building.

\section{Background Concerning Iowa State University Library's Synchronous Virtual Reference Service}

The steady increase of the instant messaging transactions at the ISU Library proved the importance of synchronous virtual reference to users. The assessment librarian and Instant Messaging (IM) reference coordinator developed a plan to advertise IM. Table tents publicizing this service were placed on all the tables, study carrels, and open study rooms in the library. After getting the support of the Dean of the Library as well as the heads of the reference department, a process was established to archive the transcripts. An Institutional Review Board (IRB) for Approval of Research Involving Humans application was also completed and sent to ISU's Office of Research Assurances to ensure that the examination of the material was approved by the parent institution. To ensure the privacy of both the user and librarian, the transcripts were stripped of any identifying information such as the date, name, or IM nickname (if any) of the user.

After the P.R. campaign, a simple statistical analysis revealed that the number of transactions more than tripled compared to the three prior months. (See figure 1 for the total numbers.) As impressive as the numbers were, they did not tell the whole story. What kind of assistance did users ask for? How did the library staff respond? Were the reference interviews successful? What were students asking? To discover the answers, the researchers conducted a close reading of the transcripts. One researcher read and reread the transcripts, taking cursory notes.

\section{Transcripts}

The transcripts are the artifacts of synchronous virtual reference transactions. These artifacts mirror the actual content of the reference query. The transcripts provided the text for the qualitative analysis. Without them, there would be no authentic method for this qualitative analysis. The ISU assessment librarian stored the transcripts on a server. For the purpose of evaluation, the researchers stripped the transcripts of any record of the times and names before uploading copies of the transcripts into ATLAS.ti.

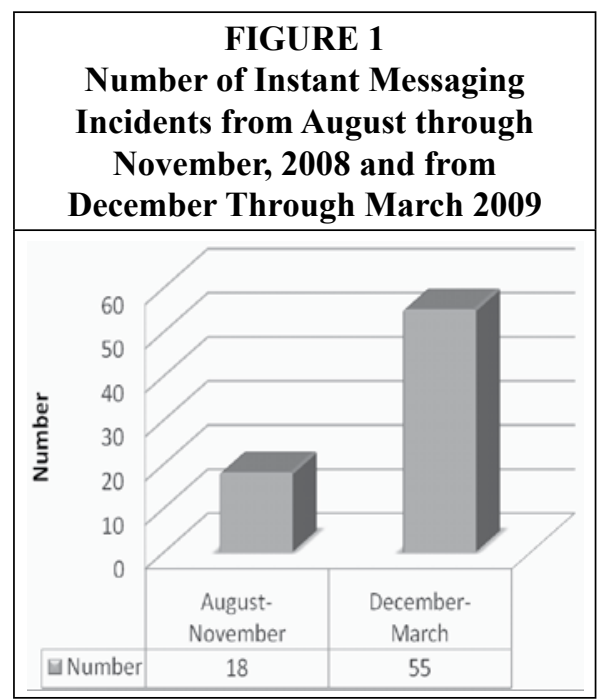




\begin{tabular}{|c|c|c|}
\hline \multicolumn{3}{|c|}{$\begin{array}{c}\text { FIGURE } 2 \\
\text { Example of a Coded Transcript }\end{array}$} \\
\hline $\begin{array}{l}\text { [11:47] meeboguest489057: Where would I start to look if I } \\
\text { were looking for information about tennis in Spain? } \\
\text { [11:48] isulibim: Hi, are you looking for current } \\
\text { information or more historical info? } \\
\text { [11:48] meeboguest489057: Relatively recent information } \\
\text { [11:48] meeboguest489057: in the past } 20 \text { years of so. } \\
\text { [11:49] isulibim: Are you familiar with the Library's } \\
\text { "Indexes and Abstracts"? } \\
\text { [11:50] meeboguest489057: Somewhat. I have used the } \\
\text { sociology one. } \\
{[11: 50] \text { isulibim: OK. Near where the Sociology one is, }} \\
\text { under } S \text {, is a database called "SportDiscus". } \\
\text { [11:50] meeboguest489057: OK. } \\
\text { [11:50] isulibim: Go into that and try this search "tennis } \\
\text { and spain" } \\
\text { [11:51] isulibim: You'll find a number of articles dealing } \\
\text { with that topic. } \\
\text { [11:51] meeboguest489057: OK. Thank you! } \\
\text { [11:51] isulbim: You're welcome. Thanks for using the } \\
\text { IM Reference service! }\end{array}$ & instruction active & query user topic \\
\hline
\end{tabular}

\section{ATLAS.ti Software}

To organize and analyze the transcripts, the researchers used the qualitative software package ATLAS.ti, which allows a researcher to code transcripts, create networks (graphical maps), and examine frequencies. Data culled from the research can be shared out in visually appealing and understandable tables, graphs, or figures. Researchers using this software must be aware of its limitations. This researcher discovered that after uploading and coding 38 transcripts, it would have been impossible to add more transcripts to the study without starting all over. Due to this fact, more transcripts were not included in the analysis. At the same time, sound qualitative research does not need a large amount of data. Instead, qualitative data relies on the depth of the analysis rather than on classifying large amounts of numeric data. ${ }^{21}$ ATLAS.ti records the number of times a particular incident occurs and relationships between different incidents. As more university administrators across the country ask for data that illustrates reasons to continue support for library services, it is imperative that refer-

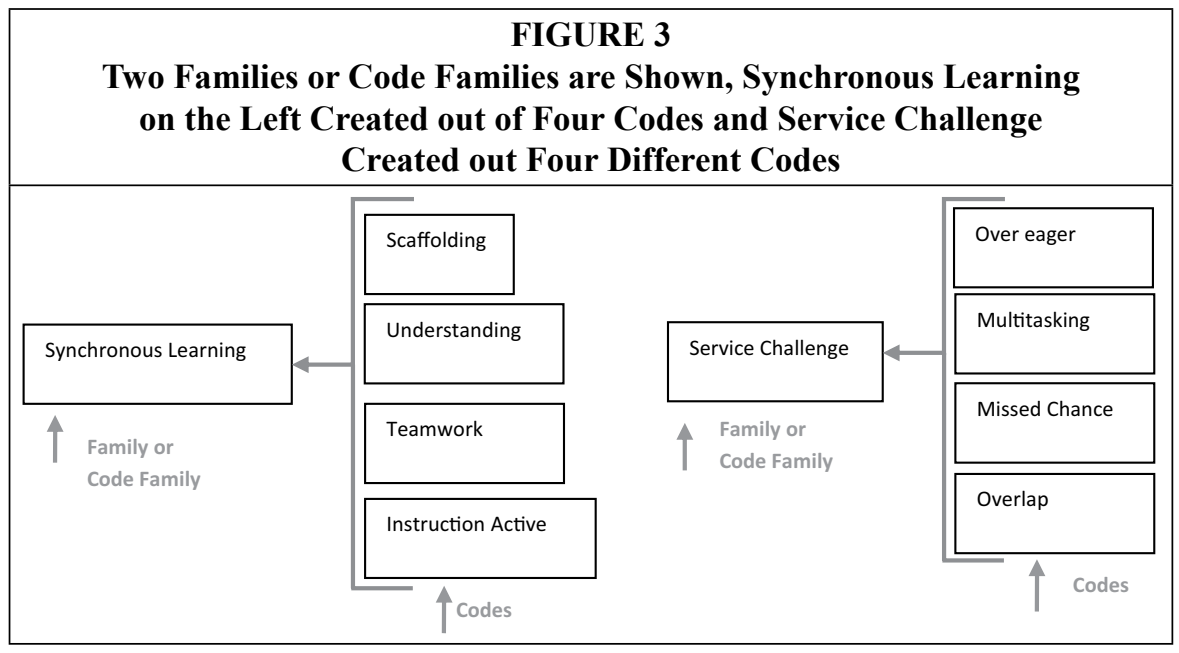


ence services assess and articulate their central role in assisting student learning.

ATLAS.ti employs qualitative research terminology. Uploaded documents are called primary documents. A group of primary documents are called a hermeneutic unit. Coding occurs on the primary documents. (See figure 2 for an example of a coded transcript.) Codes are put into groups of like kinds called families or code families. The researcher created 78 codes that developed into 28 families. (See figure 3 for an example of the code and code family relationship.)

\section{Codes}

A code's function is similar to the notes in the margins of a book. Some codes referred to phenomena that occurred only once, while other codes referred to phenomena that occurred 28 times. The software tallies the frequencies, or occurrences, of a code. Codes form the foundation for the creation of the theory generated during the research.

\section{Initial Coding Issues}

The initial process of coding is a large part of any ground theory project. The assessment librarian started coding. The first round of coding included the terms: information age, postindustrial, and knowledge. After several weeks, the researcher came to a dead end. After a long and hard look at the data, the researcher came to a hard conclusion: The conclusion revealed that a preconceived notion of the meaning or what would be "discovered" tainted the reading and coding of the data. In previous scholarly work, one of the researchers wrote extensively on the postindustrial society and educational concerns. While this research continues to influence educators, the content not only did not fit the data, it was completely inappropriate for use of the GT method. Without realizing it, the researcher started on the road of false theory.

The solution? Throw out all the old codes and start over. The researcher uploaded a few more transcripts. Next, she started reading, reviewing, and coding the data. This scary process could have led to a dead end. There was no hypothesis; what it could lead to was unknown. It was unclear if anything would come of the researchers' efforts. Anyone undertaking a GT analysis must be comfortable with starting from square one and understand that there are no knowns in regard to the data.

\section{Coding and Coding Review}

After this false start, it took several months to upload the documents and complete the final 78 codes and code families. At the start, the contextual meaning of the codes remained unclear. Additionally, some codes included concrete terms and references. Examples of concrete codes include print journal, electronic journal, print books, outlets, and printers. Some codes reflected a more conceptual description of the data found. Examples of two conceptual codes are understanding and user appreciation. The code understanding represented the phrases, "I see," "I understand," "I get it," "Now I have." This code almost always followed an exchange in which the user asked for help in finding an electronic document. The conceptual code $u$ ser appreciation captured users' texting, "Thank you," "Great help," "I appreciate ..."

During this process, the IM reference coordinator reviewed the coding, and discussion followed concerning its consistency and logic. Table 1 shows all the codes and code families created for the final research and some of the false starts or dead-end codes from the original coding process.

After several weeks of adjusting the codes, clear patterns presented themselves. The researchers created families out of the patterns and super families out of the families. Next, the researchers created visual networks (graphical maps) that illustrated code frequencies and family relationships. These networks provided a powerful and concise method for sharing data with library and uni- 


\begin{tabular}{|c|c|c|c|c|}
\hline \multicolumn{5}{|c|}{$\begin{array}{l}\text { TABLE } 1 \\
\text { Illustration of Some of the Codes and Code Families for the Three Major } \\
\text { Networks and a Few from the False Start Group (overlapping codes are in bold) }\end{array}$} \\
\hline & $\begin{array}{l}\text { Teaching and } \\
\text { Learning }\end{array}$ & Service & $\begin{array}{l}\text { Community } \\
\text { Awareness }\end{array}$ & $\begin{array}{l}\text { False Start Group } \\
\text { codes that were not } \\
\text { used }\end{array}$ \\
\hline \multirow{21}{*}{$\begin{array}{l}\text { Codes in } \\
\text { Alphabetical } \\
\text { Order }\end{array}$} & Active Teaching & Abrupt ending & Alumni & Action Verbs \\
\hline & $\begin{array}{l}\text { Asynchronous } \\
\text { Teaching }\end{array}$ & $\begin{array}{l}\text { Appreciation } \\
\text { Librarian }\end{array}$ & $\begin{array}{l}\text { Ames Public } \\
\text { Library }\end{array}$ & Advanced Librarian \\
\hline & $\begin{array}{l}\text { Asynchronous } \\
\text { Learning }\end{array}$ & $\begin{array}{l}\text { Appreciation } \\
\text { Staff }\end{array}$ & $\begin{array}{l}\text { Bookstore } \\
\text { Textbook }\end{array}$ & Advanced User \\
\hline & Catalog & $\begin{array}{l}\text { Appreciation } \\
\text { User }\end{array}$ & Catalog & $\begin{array}{l}\text { Communication } \\
\text { within the Library }\end{array}$ \\
\hline & $\begin{array}{l}\text { Electronic } \\
\text { Journal }\end{array}$ & Emoticon & Circulation & Facts \\
\hline & $\begin{array}{l}\text { Harvard Business } \\
\text { Review }\end{array}$ & $\begin{array}{l}\text { Exclamation } \\
\text { Point }\end{array}$ & Closing & Formal \\
\hline & $\begin{array}{l}\text { Indexes \& } \\
\text { Abstracts }\end{array}$ & $\begin{array}{l}\text { Extreme } \\
\text { Appreciation } \\
\text { User }\end{array}$ & Computer & Informal \\
\hline & Information & Introduction & Copy Center & Information Age \\
\hline & Instruction Active & Length & $\begin{array}{l}\text { Design Reading } \\
\text { Room }\end{array}$ & Journal \\
\hline & $\begin{array}{l}\text { Instruction } \\
\text { Procedural }\end{array}$ & Location & $\begin{array}{l}\text { Distance } \\
\text { Education }\end{array}$ & Location \\
\hline & Learning & Missed Chance & $\begin{array}{l}\text { Electronic } \\
\text { journal }\end{array}$ & No Punctuation \\
\hline & Magazine & Multitasking & $\begin{array}{l}\text { External } \\
\text { Community }\end{array}$ & Postindustrial \\
\hline & Multiple Steps & Overlap & Floors & Search \\
\hline & New Knowledge & Problem & $\begin{array}{l}\text { Greenlee } \\
\text { Reading Room }\end{array}$ & Strategy \\
\hline & Procedural & Symbol & $\begin{array}{l}\text { Harvard } \\
\text { Business } \\
\text { Review }\end{array}$ & User \\
\hline & Scaffolding & $\begin{array}{l}\text { Technology } \\
\text { Problems }\end{array}$ & $\begin{array}{l}\text { Indexes \& } \\
\text { Abstracts }\end{array}$ & $\begin{array}{l}\text { User Offering } \\
\text { Information }\end{array}$ \\
\hline & Search & & Information & $\begin{array}{l}\text { User Query Self } \\
\text { Search }\end{array}$ \\
\hline & Skill Building & & Interlibrary loan & \\
\hline & $\begin{array}{l}\text { Synchronous } \\
\text { Learning }\end{array}$ & & $\begin{array}{l}\text { Internal } \\
\text { Departments }\end{array}$ & \\
\hline & Teamwork & & $\begin{array}{l}\text { Internal Library } \\
\text { Community }\end{array}$ & \\
\hline & & & IT & \\
\hline
\end{tabular}




\begin{tabular}{|l|l|l|l|l|}
\hline \multicolumn{5}{|c|}{ TABLE 1 } \\
Illustration of Some of the Codes and Code Families for the Three Major \\
Networks and a Few from the False Start Group (overlapping codes are in bold)
\end{tabular}

versity administrators. Figure 4 shows the relationship between codes, families, super families, and networks.

\section{Networks}

Codes provide a foundation for the networks created. The entire GT model is analogous to a skyscraper: the codes provided the building's foundation; the code families were the floors, and the three networks were the pinnacles rising above the top level. The researchers of this study created codes, code families, and, finally, networks. Some codes overlapped and "lived" in two networks.

\section{Results}

The analysis of the codes led to the theoretical creation of families and of three networks. In this case, the networks created were labeled "Community Awareness," "Service Quality," and "Teaching 
and Learning." (For representations of the "Community Awareness," "Service Quality," and "Teaching and Learning" networks, see figures 4,5 , and 6 , respectively.)

In the interest of brevity, this paper will only discuss the family, or category, "Synchronous Learning" in the "Teaching and Learning" network, and "Service Challenge" in the "Service Quality" network. The Synchronous Learning family provides a wealth of data describing the collaborative learning that occurs within the IM synchronous virtual reference service at Iowa State University. The Service Challenge family illustrates how technology and staffing can adversely affect learning. This paper describes the multifaceted "business" that occurs within the IM virtual reference service at Iowa State University.

\section{Discussion of the Synchronous Learning Narrative Data}

Developing the "Synchronous Learning" family within the "Teaching and Learning" construct involved building meaning from the codes. The four codes in this family are teamwork, scaffolding, understanding, and instruction activity. Groundedness refers to the number of text references and density or interrelated

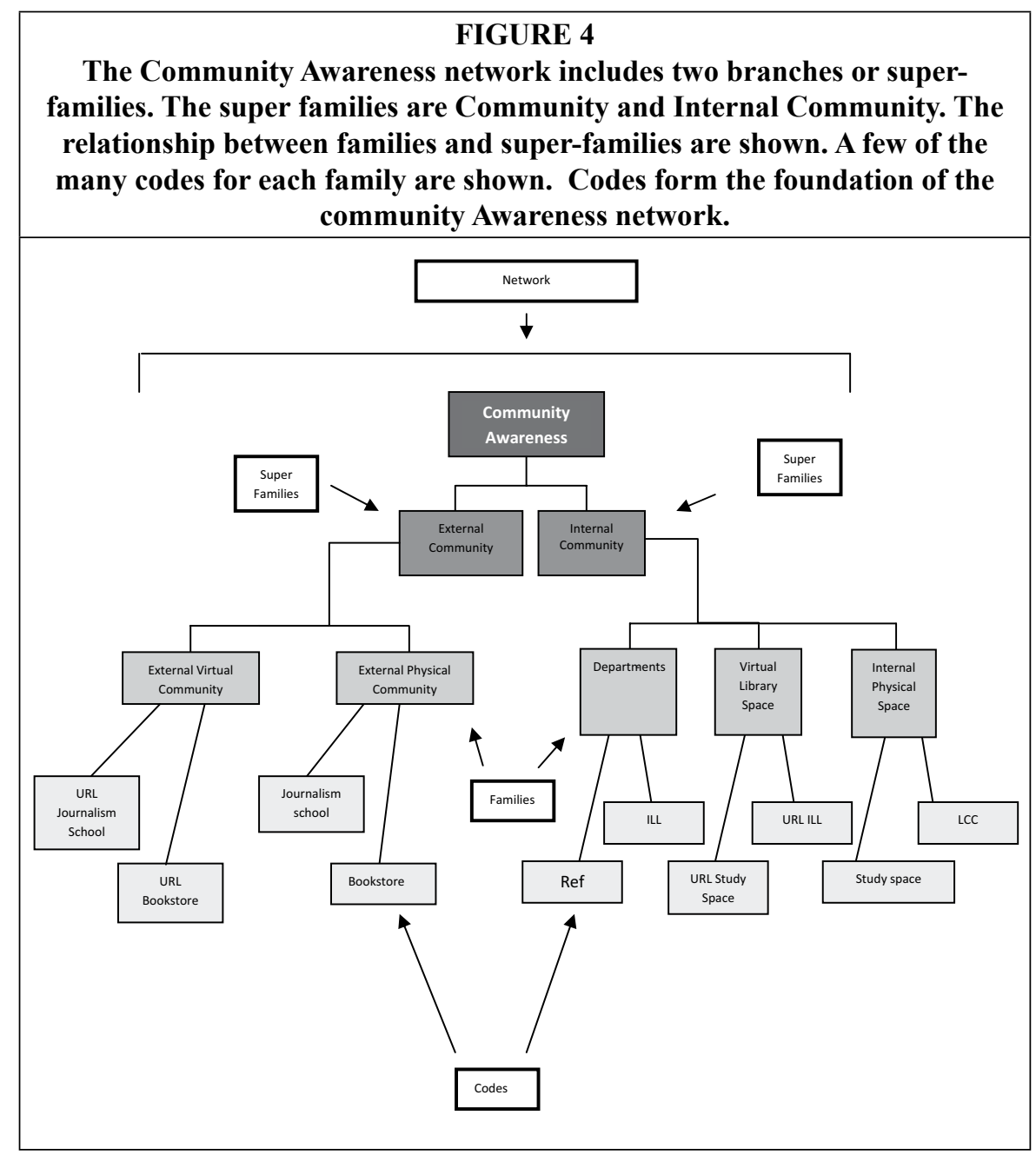




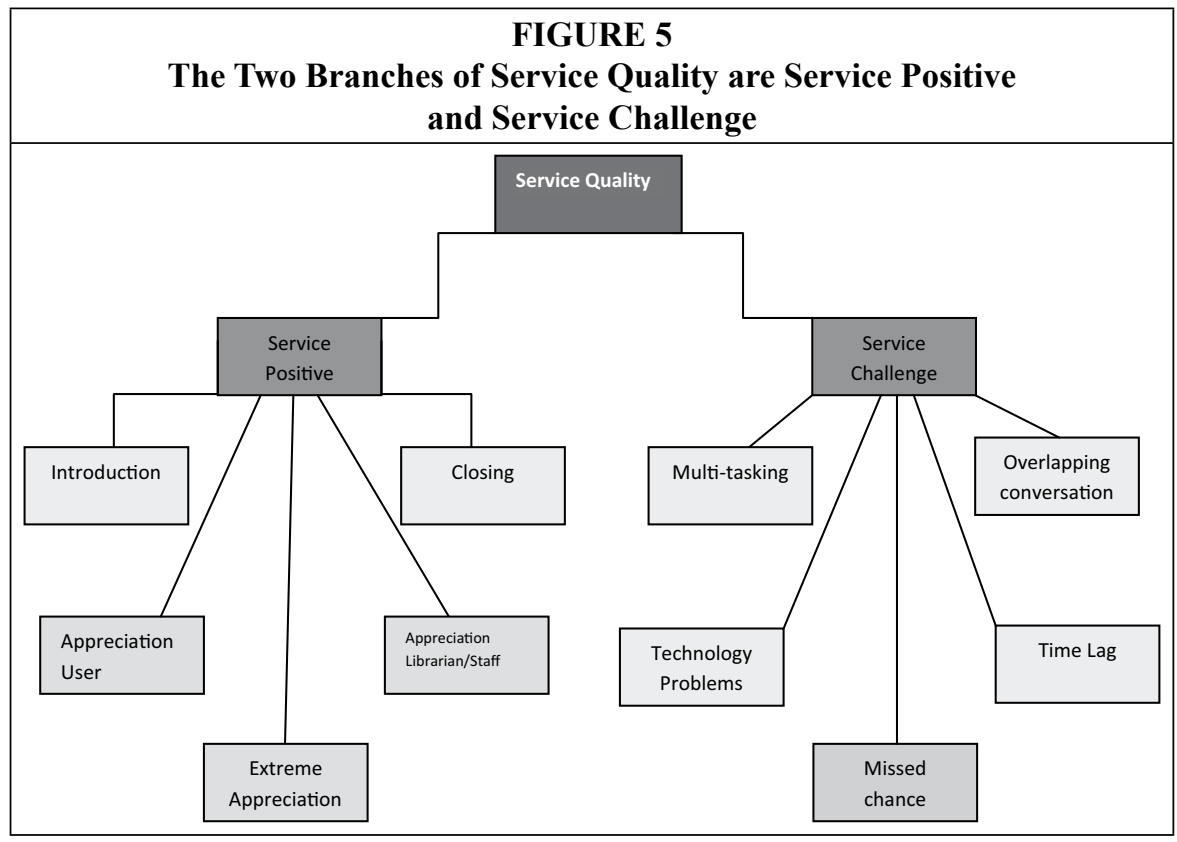

\section{FIGURE 6}

The Network Teaching and Learning is Represented with the Super Code Teaching and Learning, Family Codes Asynchronous Learning and Synchronous Learning, and the Accompanying Codes

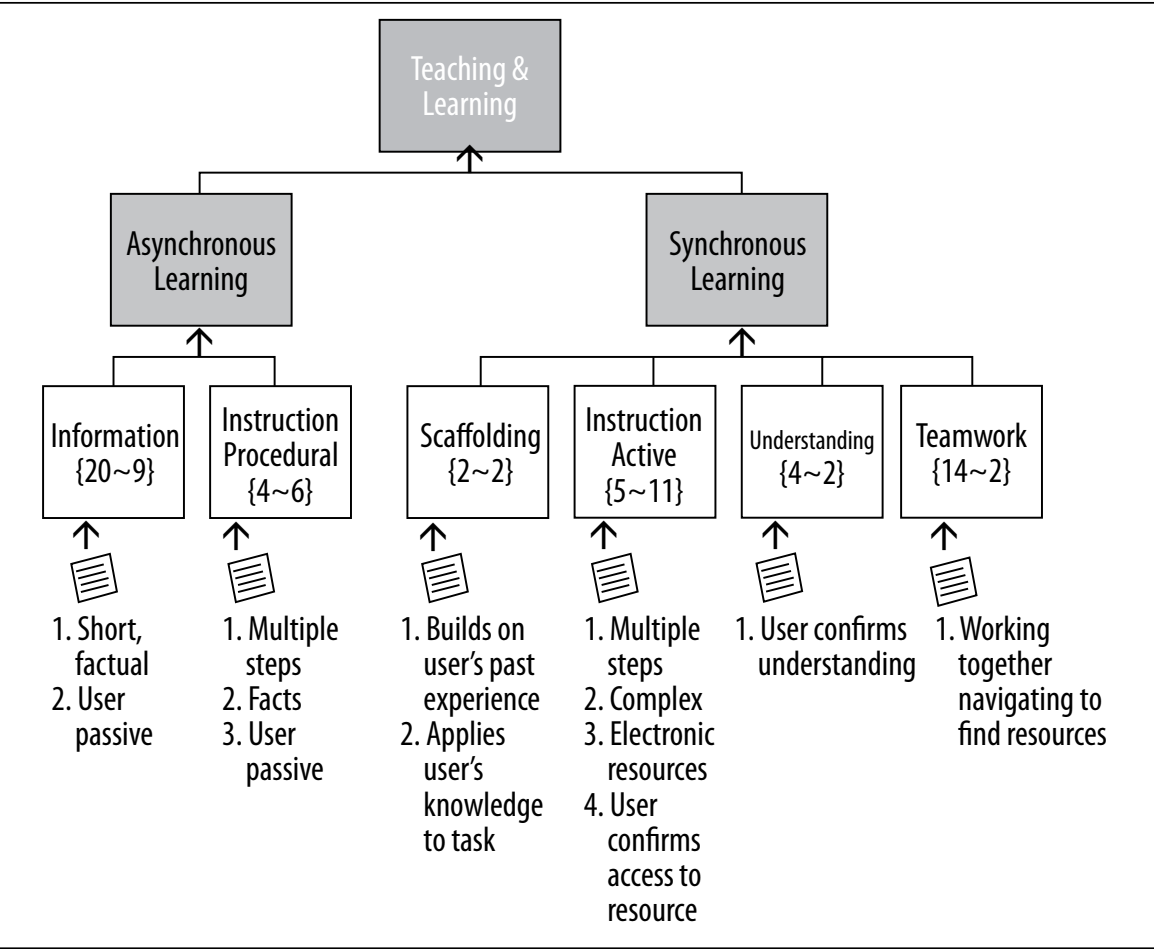


or connected these four codes are to other codes.

One important conceptual code involved scaffolding. Scaffolding is a term that comes from educational theory and practice. By definition, scaffolding "enables the learner to continue with his learning process in an autonomous, self-sufficient manner" when instruction is complete. ${ }^{27}$ The interview below illustrates the concept of scaffolding:

Reference Librarian: Are you familiar with the Library's "Indexes and Abstracts"?

User: Somewhat. I have used the sociology one.

Reference Librarian: OK. Near where the Sociology one is, under S, is a database called "SportDiscus."

In this example the reference librarian uses queries akin to "Are you familiar with...?" to determine whether the user has any prior knowledge relating to the reference question at hand. The navigational cues that form the rest of these interviews are predicated on the user's prior knowledge.

Within the transcripts there was a oneto-one relationship between the concept of scaffolding and the concept of understanding. In figure 7 , the user confirms their understanding of the reference librarian's explanations. Understanding is usually characterized by statements such as "I think," "I understand," or "I see." Another example:

Reference Librarian: did you get that you need to go to advanced search?

User: Ye

User: *Yes

Reference Librarian: ok

Reference Librarian: There is a limiter by language

User: Aah I see it

The tone in the final line implies that the user sees something that he or she has not used before by typing "Aah I see it." The user has gained an understanding of a particular way to search. This example illustrates the user's sense of success in comprehending how to search for needed material.

During a synchronous learning experience the transcripts show that the user and librarian form a temporary partnership in the quest for an answer. There is a give and take in the conversation. Figure 7 contains the code family "Teamwork." In figure 7, a sense of teamwork is developing as the librarian says, "Let me know when you are there." After the user confirms, the conversation continues:

Reference Librarian: OK, now go into the database - click on the link again, and then click on the "Proceed" button on the next page

User: and then search through the toolbar there? ...

User: I think I figured it out. Thank you very much!!

Reference Librarian: wait

User: ?

Reference Librarian: did you get to the part where you enter the journal title

User: I went there, and now I am just searching for [the journal]

Reference Librarian: put [the journal title] in the box that says "Journal Title" and leave everything else blank

User: Okay Thank you!!!

The user indicates puzzlement with a "?" The user's statement that they are "just searching for the journal title" is another learning opportunity. The librarian provides more instruction ensuring that the user's search is efficient. Active instruction parallels teamwork. Active instruction is coded as the whole of the transcript in figure 7 . The librarian and the user, as detailed in the transcript of figure 7 , dynamically participate during the interview. Parts of the elements of transcripts coded for the active instruc- 


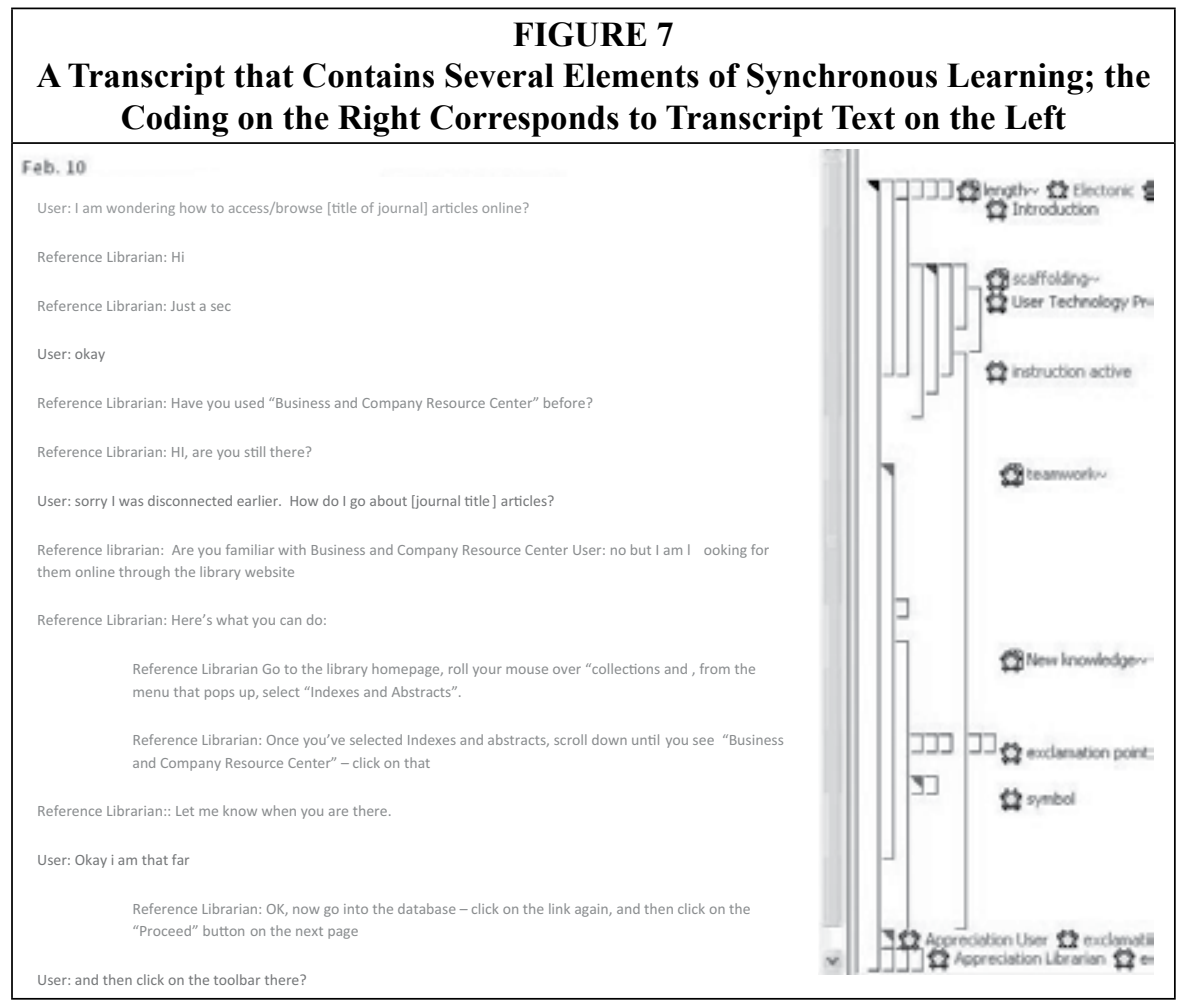

tion include the librarian texting, "here's what you can do," "let me know when you are there." For the user, the phrases that helped build code family active instruction included "... Okay I'm that far," "... Click on the toolbar?" "... I figured it out," and "?" The user checks, questions, and then establishes his or her satisfaction by typing "Okay Thank you!!!"

Table 2 provides excerpts of each of the synchronous learning codes. The scaffolding examples use the introductory phrase "Are you familiar with ..." then proceed to direct the communication from a point with which the user is already acquainted. Scaffolding incidents are always near the new knowledge code. Terms like "Ah, I see," "Got it ..." "I think I figured it out" are elements of new knowledge. Active instruction includes phrases such as "Did you get that ..." "Check that ..." "Let me know ..." The teamwork example shows the librarian and guest going back and forth checking each other. This includes verbiage that supports interaction such as "I will check" or "Is that right?" Table 3 provides fuller examples. A delicate electronic ballet plays out between the user, who feels that he or she understands, and the librarian who wants to confirm understanding. The two people form a temporary team checking and supporting each other to a successful conclusion. The user logs off with a full real-time experience on how to use a particular database. The two people form a temporary team checking and supporting each other to a successful conclusion. The user logs off with a full real-time experience on how to use a particular database.

\section{Quantifying the Synchronous Learning Narrative Data}

In GT, groundedness and density validate the theoretical strength of a construct. Groundedness refers to the number of text references of a code. Density refers to how interrelated a code is to other codes. 
TABLE 2

Excerpts Representing Codes in the Synchronous Learning Family

\begin{tabular}{|c|c|}
\hline Teamwork Examples & Scaffolding Examples \\
\hline $\begin{array}{l}\text { Isulibim: What date are you looking for? } \\
\text { Guest: I need... } \\
\text { Isulibim: Let me check } \\
\text { Guest: any luck? }\end{array}$ & $\begin{array}{l}\text { Isulibim: Are you familiar with Business } \\
\text { and Company Resource Center? } \\
\text { Guest: no, but I am looking for them online } \\
\text { through the library website } \\
\text { Isulibim: Here's what you can do: }\end{array}$ \\
\hline $\begin{array}{l}\text { Isulibim: Did you try the "Get It @ ISU" } \\
\text { button? } \\
\text { Guest: yes and it said... Does that sound } \\
\text { right? } \\
\text { Isulibim: yes, okay go... }\end{array}$ & $\begin{array}{l}\text { Isulibim: Are you familiar with the Li- } \\
\text { brary's "Indexes and Abstracts"? } \\
\text { Guest: Somewhat. I have used the sociol- } \\
\text { ogy one. } \\
\text { Isulibim: OK. Near where the Sociology . }\end{array}$ \\
\hline Understanding Examples & Active Instruction \\
\hline $\begin{array}{l}\text { Isulibim: Leave everything else blank and } \\
\text { hit enter, and you'll get the entire list of } \\
\text { online ... starting from the most recent } \\
\text { Guest: I think I figured it out }\end{array}$ & $\begin{array}{l}\text { Isulibim: did you get that you need to go to } \\
\text { advanced search? } \\
\text { Guest: Yes* } \\
\text { Isulibim: Check out... }\end{array}$ \\
\hline $\begin{array}{l}\text { Isulibim: ok } \\
\text { Isulibim: There is a limiter by language } \\
\text { Guest: Aah I see it }\end{array}$ & $\begin{array}{l}\text { Isulibim: Click on the "My Value Line" } \\
\text { when you log in } \\
\text { Isulibim: Let me know when you're there. } \\
\text { Guest: Okay i am that far } \\
\text { Isulibim: OK, now go into the database... } \\
\text { Guest:k } \\
\text { Isulibim: Good now click }\end{array}$ \\
\hline
\end{tabular}

Table 2 shows how often the four codes of synchronous learning appear in the transcripts. Additionally, the density of each code illustrates how interrelated a code is to other codes, families, or networks. One important code, scaffolding, appears two times (or has a groundedness of 2), and its density or interrelatedness with other codes is also 2 .

The groundedness for new knowledge is 4; for teamwork, 15; and for active instruction, 4 . The density for understanding is 2; instruction active, 11 ; and teamwork, 10 . At least three of these codes have to appear together to create a synchronous learning experience. The density or interrelatedness between these codes is high, but the interrelatedness of all these codes correlates to the elements of teaching and learning. These results form the foundation of synchronous learning family in the teaching and learning network.

A total of 28 out of 38 transcripts formed the teaching and learning network; this is 74 percent of all the transcripts. Four of those transcripts formed the synchronous learning family. The other ten elements belong to the service quality network and/or the community awareness network. It is important to note that one transcript can be a member

\begin{tabular}{|l|c|c|}
\hline \multicolumn{3}{|c|}{ TABLE 3} \\
$\begin{array}{c}\text { The Grounded and Density of the Four Code } \\
\text { Families in Synchronous Learning }\end{array}$ \\
\hline $\begin{array}{l}\text { Code Elements of } \\
\text { Synchronous Learning }\end{array}$ & $\begin{array}{c}\text { Groundedness } \\
\text { of Each Code }\end{array}$ & $\begin{array}{c}\text { Density of } \\
\text { Each Code }\end{array}$ \\
\hline Teamwork & 14 & 9 \\
\hline Scaffolding & 2 & 2 \\
\hline Understanding & 4 & 2 \\
\hline Instruction Active & 5 & 11 \\
\hline
\end{tabular}


of one or more networks. The data in table 4 shows that, 11 percent of the time, synchronous learning occurs during a synchronous virtual reference interview. Of these four transcripts, there was a 100 percent success rate in the users obtaining the information they needed. All five of these transcripts illustrated user satisfaction, and four illustrated extreme user satisfaction. Eight transcripts had two codes from this network. Because codes often overlap into different theoretical networks, the times and percentages illustrated in table 4 do not add up to 100 percent.

\section{Discussion of the Service Challenge Narrative Data}

The service challenge family posed the greatest concern regarding services and the potentially negative impact on teaching and learning opportunities and on accessing information. See figure 5 for an illustration of the service challenge family within the service quality network.

The characteristics of the service challenge family included the codes "time lag," "multitasking," "missed chance," and "technology problems." Below is an example of a "time lag."

\section{User: Hello??}

User: I am trying to request an item ... and it says, "Recall/hold marked, but item status is not requestable."

Reference librarian: Could you tell me the title of the journal so I can see what you're looking at?

Reference librarian: Hope you haven't given up-I had someone

\begin{tabular}{|c|c|c|c|c|c|}
\hline \multicolumn{6}{|c|}{$\begin{array}{c}\text { TABLE } 4 \\
\text { Synchronous Virtual Reference Data }\end{array}$} \\
\hline All Data & $\begin{array}{l}\text { Number of } \\
\text { Transcripts }\end{array}$ & $\begin{array}{c}\text { Total } \\
\text { Minutes all } \\
\text { Transcripts }\end{array}$ & $\begin{array}{c}\text { Average } \\
\text { Number of } \\
\text { Minutes per } \\
\text { Interview }\end{array}$ & $\begin{array}{c}\text { Percentage } \\
\text { of Total } \\
\text { Interviews }\end{array}$ & $\begin{array}{l}\text { Percentage } \\
\text { of Total } \\
\text { Interview } \\
\text { time }\end{array}$ \\
\hline $\begin{array}{l}\text { All Synchronous Virtual } \\
\text { Reference }\end{array}$ & 38 & 303 & 7.9 & $100 \%$ & $100 \%$ \\
\hline Network Data & $\begin{array}{l}\text { Number of } \\
\text { Transcripts }\end{array}$ & $\begin{array}{c}\text { Total } \\
\text { Minutes } \\
\text { for Each } \\
\text { Network }\end{array}$ & $\begin{array}{c}\text { Average } \\
\text { Number of } \\
\text { Minutes per } \\
\text { Interview }\end{array}$ & $\begin{array}{l}\text { Percentage } \\
\text { of Total } \\
\text { Interviews }\end{array}$ & $\begin{array}{c}\text { Percentage } \\
\text { of Total } \\
\text { Interview } \\
\text { Time }\end{array}$ \\
\hline $\begin{array}{l}\text { Teaching and Learning } \\
\text { Network }\end{array}$ & 28 & 262 & 9.3 & $74 \%$ & $86 \%$ \\
\hline $\begin{array}{l}\text { Community Awareness } \\
\text { Network }\end{array}$ & 23 & 176 & 7.6 & $61 \%$ & $58 \%$ \\
\hline Service Quality Network & 30 & 273 & 9.1 & $78 \%$ & $79 \%$ \\
\hline $\begin{array}{l}\text { Data for Synchronous } \\
\text { Learning and Service } \\
\text { Challenge Families }\end{array}$ & $\begin{array}{l}\text { Number of } \\
\text { Transcripts }\end{array}$ & $\begin{array}{c}\text { Total } \\
\text { Minutes } \\
\text { for Each } \\
\text { Family }\end{array}$ & $\begin{array}{c}\text { Average } \\
\text { Number of } \\
\text { Minutes per } \\
\text { Interview }\end{array}$ & $\begin{array}{l}\text { Percentage } \\
\text { of Total } \\
\text { Interviews }\end{array}$ & $\begin{array}{c}\text { Percentage } \\
\text { of Total } \\
\text { Interview } \\
\text { Time } \\
\end{array}$ \\
\hline $\begin{array}{l}\text { Synchronous Learning } \\
\text { Family (in which at least two } \\
\text { of the following occur: scaf- } \\
\text { folding, instruction active, new } \\
\text { knowledge, or teamwork) }\end{array}$ & 4 & 52 & 17.3 & $11 \%$ & $15 \%$ \\
\hline $\begin{array}{l}\text { Service Challenge (in } \\
\text { which one or more of the } \\
\text { following occur: time lag, } \\
\text { overlapping conversation, } \\
\text { multitasking, technology } \\
\text { problems, missed chance) }\end{array}$ & 8 & 117 & 14.6 & $21 \%$ & $35.84 \%$ \\
\hline
\end{tabular}


at the desk just as you asked your question

In this instance, because the librarian is multitasking by helping an in-person user, the virtual user waited three minutes after his or her IM query.

Missed chance, another service challenge, created a powerful negative impact on teaching and learning. In the following interview, the user is looking for material. After four minutes, the following dialogue takes place:

User: $\mathrm{i}$ doubt that is the one ...

User: how do i search for it myself?
Reference librarian: There is this one: [Title of media given]

Reference librarian: There are a few others ...

User: not that either..

Reference librarian: Please hold

"How do I search for it?" - a query that is music to a librarian's ears - is never acknowledged. Instead, the eager librarian provides the user with a title pasted in the Meebo widget. The user states it isn't the right one and used words like "sorry, I am not sure." Eventually, the librarian, stumped, asked the user for his or her e-mail address and signed off,

\section{TABLE 5}

Excerpts Representing Codes in the Service Challenge Network

\begin{tabular}{l}
\hline Overlap Examples \\
\hline Guest: And are you ...? \\
Isulibim: Yes - . \\
Isulibim: hold on a second - ...I want to \\
check on something for you. \\
Guest: And how can I? I need that document \\
Guest: ok
\end{tabular}

Isulibim: Do you need it online or in print?

Guest: Can I access this from the library website Technology Issues

Isulibim: Hope you didn't sign off-I totally forgot that if someone logs in to IM, it doesn't "pop up" on my screen - should not have had something over the top of my IM page.

Isulibim: Let me see.

Guest: Online

Isulibim: Let me see.

Time Lag Examples

Isulibim: even

a moment later...

Guest: Oh no! My popup blocker reset the chat window. Could you sent that link once more?

Guest: And are you ...?

Isulibim: Yes - .

Isulibim: hold on a second - I want to check on something for you.

Guest: And how can I? I need that document Guest:: ok

Isulibim: Thanks; Please hold

Guest: not that either..

Isulibim: Please hold

Missed Chance Examples

Isulibim: There is this item...

Guest: i doubt that is the one

Guest: how do i search for it myself?

Isulibim: There is this one:

Isulibim: $\mathrm{Hi}$ !

Isulibim: Just a sec:

Guest: okay

Isulibim: Have you used ...

Isulibim: $\mathrm{Hi}$, are you still there

Isulibim: Hello

Isulibim: ?

\section{Multitasking}

Isulibim: Hope you haven't given up-I had someone at the desk just as you asked your question. 
stating that the librarian would send the information when possible. In total, this interview took 16 minutes. The result was that the user did not obtain the needed material nor did he or she learn, despite the request, an independent search strategy. Of all the service challenge categories, the "missed chance" code has the starkest potential to adversely affect users' desire to request reference assistance. The missed chance represents the antithesis of synchronous learning. One must ponder, after reviewing synchronous learning research, whether a user would come back to use this service.

\section{Quantifying the Service Challenge Narrative Data}

The service challenge family within the service challenge network occurred in eight transcripts. Twenty-three percent of all transcripts contained a service challenge. Multitasking either by the user or librarian was identified in four transcripts. The code overlap had a groundedness of 2. Technology issues occurred in four transcripts. Time lag occurred in five transcripts with a density of 3. Additionally, multitasking, overlap, and missed chance had a density of 3 . The data in table 1 shows service challenges occur 18.42 percent of the time. Elements of service challenge include the user not obtaining the necessary information, the librarian uncertain if the user is still participating, the user and/ or librarian texting over each other, the window of the synchronous virtual reference application - in this research Meebo application-popping open or closing. Textual examples of service challenge can be found in table 5 .

Table 4 shows that the total time for all synchronous virtual reference was 293 minutes. Service challenge consumed a total of 105 minutes or 35.84 percent of the time. One interview that illustrates missed chance was 18 minutes long, not counting the time the user was on hold. It must be noted that several service challenge incidents were "saved" through skillful reference redirection. The contextual reading of the transcripts reveals that the service challenges most often stem from lack of knowledge or lack of standards for dealing with the synchronous virtual reference application and not from poor reference skills.

Four of the eight queries in the service challenge dealt with electronic material access. Three of the synchronous learning incidents focused on accessing databases or electronic journals. The fourth dealt with library catalog instruction for finding a book. In only two of these incidents did the user obtain the information he or she needed. In only three of the eight transcripts did the user formally sign-off and in only two did the user show appreciation.

\section{Recommendations Resulting from the Research Training}

Developing a GT for any assessment should have practical impact. ${ }^{22}$ Examining the transcripts using a contextual analysis and then quantifying this data lead the researchers to conclude that with training it was possible for synchronous virtual reference to occur more often. Developing staff training regarding the concepts of scaffolding, active learning and learning theory such as constructivism and authentic learning could improve the service provided at the library. Additionally, discussing how to use the IM tool to avoid time lags, overlap, and multitasking with reference department provided useful and practical skills that positively impacted service. Staff development issues were presented to the reference department and the Dean of the Library as part of a summary of the results. The reference department heads, the IM Reference coordinator, and assessment librarian are developing best-practice guidelines for virtual reference. The library's staff intranet site will contain communication standards for virtual reference and will provide reference librarians with a list of general do's and don'ts. 
It is possible that training will allow a greater number of "teaching and learning" experiences to occur in synchronous virtual reference transactions, providing long-term benefits to the user, and creating a positive "word on the street" buzz concerning user-centered service at the library. From this study, the researchers developed five best-practice recommendations for synchronous virtual reference. They were:

1. Provide a dedicated environment in which library personnel are only conducting synchronous virtual reference. This will prevent multitasking and service frustration.

2. Provide an opening and closing: when appropriate, use statements such as "Hello, ISU library," and "Thank you for using our service." This provides the users with a beginning and ending point for the interview.

3. Listen to the user: when assigned synchronous virtual reference duties, staff should be trained on dynamics of the service such as time lags in conversation, overlapping conversations, and pausing when appropriate, as ways to improve service.

4. Provide time for simulation during which paired staff can simulate the virtual reference process and practice their skills.

5. Provide a mentoring system during which library personnel can view and reflect on best practice.

6. Provide staff development that focuses on providing more teaching and learning opportunities during synchronous virtual reference by providing teaching and communication tips in the area of scaffolding, teams, and active instruction.

Interestingly, the first five of the above recommendations complement the findings of Lili Luo. ${ }^{23}$

The sixth recommendation developed directly from the theoretical model of the synchronous learning branch. The research, theoretical detail, and accuracy of the synchronous learning family directly impacted the sixth recommendation. The sixth recommendation provided a platform of informal and formal discussion among library peers.

\section{Technology}

Technology issues were addressed at the departmental level. The main technology recommendations dealt with homepage real estate and formalized data storage procedures. Previously, a link for initiating a virtual reference dialogue was two clicks away from the homepage. As a result of this research, a reference widget with scrolling images of librarians (similar to the one currently found at University of Washington's library homepage) will be placed centrally on the ISU Library homepage when the library Web site overhaul is complete. Discussions are taking place with the library's IT department regarding a programming code that will automatically store transcripts. The reference statistics keeper will maintain the records for evaluation purposes, stripping the transcripts of names and times to ensure the privacy of the user and the librarian.

\section{Conclusion}

GT provided a method for conducting an in-depth analysis of the Meebo IM transcripts by coding data. The discrete codes with the service challenge were compared to other datasets, contextualized, and itemized. Once this part of the research was complete, the networks became the structure that supports the theory that synchronous virtual reference can simulate synchronous virtual learning. This analysis indicates that IM is an important teaching and learning service. Through addressing staff development and technology issues, this service can provide an even greater teaching and learning experience for users.

The synchronous learning subnetwork of the larger teaching and learning network indicates ISU Library's important role in steering students to important 
scholarly resources and enhancing their research navigational skills. ISU defines the educational priority as follows: "Strengthen undergraduate, graduate, and professional education to enhance student success at Iowa State University and beyond ... [by] Strengthen[ing] students' critical thinking ... and communication skills." ${ }^{24}$ Synchronous learning opportunities provide a sound pedagogical method that develops students' critical and independent learning skills. ${ }^{25}$ Synchronous learning provides unique opportunities when compared to asynchronous learning. ${ }^{26}$ This paper illustrates that synchronous virtual reference at its best affords the delivery method most relevant to students, while providing an authentic and rigorous approach to teaching research skills. The research indicated that, when synchronous virtual reference takes on aspects of synchronous learning, it fits within the larger educational discussion and theories regarding online learning and communication.

Additionally, this service provides realtime feedback. As access to information becomes more and more instantaneous, the successful implementation of synchronous virtual reference becomes more and more important. ${ }^{27}$ The fact that users are asking real-time questions relevant to their information needs parallels the characteristics of constructivist learning. Constructivist learning helps create deep knowledge for the learner..$^{28}$ The analysis of the transcripts builds a strong case for the centrality of synchronous virtual reference in authentic learning. It also reveals how virtual reference is a natural fit for teaching and learning about electronic resources. Through instantaneous feedback, the reference librarian can respond to questions and the user can implement the instructions.

In the future, by increasing the staff's skills, ISU Library can promote the users' learning and the library's most valuable asset: the collection (and not just any part of the collection, but especially electronic resources). Stellar service ensures libraries' continued relevance in their learning and research communities. ${ }^{29}$ This GT analysis illustrated the rich, complex dialogue between library users and reference librarians during synchronous virtual reference. It also revealed the need to train staff to solve technology problems and, most important, to listen to library users to increase the teaching and learning experience of the whole community. Library personnel must be provided with information concerning the central role that synchronous virtual reference can play in users' learning and discovery experiences.

This research involves 38 transcripts at a land grant and Tier One research institution. Further research could examine synchronous virtual reference services at different types of colleges and universities. It would be interesting to see if this study could be replicated and what the results would be in different libraries at different types of institutions. A poststudy examining the transcripts for the number of synchronous learning opportunities and the number of service challenges could provide information regarding the effectiveness of training. As synchronous communication becomes the norm and synchronous learning opportunities increase, libraries must understand the important role they play in providing authentic learning opportunities to build research skills and to provide access to library collections.

\section{Notes}

1. Dana Goodyear, "I Love Novels," The New Yorker 84, no. 42 (2008): 62-67.

2. British Council and the British Broadcasting Corporation, Synchronous Learning. Available online at www.teachingenglish.org.uk/think/knowledge-wiki/synchronous-learning. [Accessed 28 May 2010].

3. Ruth A. Pagell, “The Virtual Reference Librarian Using Desktop Videoconferencing for 
Distance Reference," The Electronic Library 14, no. 1 (1996): 21-26.

4. Joel Cummings, Lara Cummings, and Linda Frederiksen, "User Preferences in Reference Services: Virtual Reference and Academic Libraries," portal: Libraries and the Academy 7, no. 1 (2007): 81-96.

5. Robin Veal and Erika Bennett, "The Virtual Library Liaison: A Case Study at an Online University," Journal of Library Administration 49, nos. 1 and 2 (2009): 161-70.

6. Nahyun Kwon, "User satisfaction with referrals at a collaborative virtual reference service," Information Research 11, no. 2 (2006): paper 246. Available online at http://InformationR.net/ir/11-2/ paper246.html. [Accessed 10 March 2010].

7. Marie L. Radford, “Encountering Virtual Users: A Qualitative Investigation of Interpersonal Communication in Chat Reference," Journal of the American Society for Information Science and Technology 57, no. 8 (2006):1046-59.

8. Ian J. Lee, "Do Virtual Reference Librarians Dream of Digital Reference Questions? A Qualitative and Quantitative Analysis of Email and Chat Reference," Australian Academic E Research Libraries 35, no. 2 (2004): 95-110.

9. Kathleen M. Kern, Virtual Reference Best Practices: Tailoring Services to Your Library (Chicago: American Library Association, 2009), 1-148.

10. Lili Luo, "Effective Training for Chat Reference Personnel: An Exploratory Study," Library $\mathcal{E}$ Information Science Research 31, no. 4 (2009): 210-24.

11. Darlene Weingand, "Grounded Theory and Qualitative Methodology," IFLA Journal 19, no. 1 (1993): 17-26.

12. Ibid.

13. Constance A. Mellon, "Library Anxiety: A Grounded Theory and Its Development," College and Research Libraries 47, no. 2 (1986): 160-65.

14. Wooseob Jeong, "Unbreakable Ethnic Bonds: Information-seeking Behavior of Korean Graduate Students in the United States," Library E Information Science Research 26, no. 3 (2004): 384-400.

15. Yazdan Mansourian and Tarbiat Moallem, "Contextualization of Web Searching: A Grounded Theory Approach," The Electronic Library 26, no. 2 (2008): 202-14.

16. David Ellis, "Modeling the Information-seeking Patterns of Academic Researchers: A Grounded Theory Approach," Library Quarterly 63, no. 4 (1993): 469-87.

17. Margaret Ostrander, "Talking, Looking, Flying, Searching: Information Seeking Behavior in Second Life," Library Hi Tech 26, no. 4 (2008): 512-24.

18. Jillian Rhine, What Is Grounded Theory? Grounded Theory Institute. Available online at www.groundedtheory.com/what-is-gt.aspx. [Accessed 10 March 2010].

19. Barney G. Glaser and Anselm L. Strauss, The Discovery of Grounded Theory: Strategies for Qualitative Research (Chicago: Aldine Publishing Company, 1967).

20. Barney G. Glaser, Theoretical Sensitivity: Advances in the Methodology of Grounded Theory (Mill Valley, Calif.: The Sociology Press, 1978): 5-25.

21. Jerome Kirk and Marc L. Miller, Reliability and Validity of Qualitative Research (Newbury Park, Calif.: SAGE Publications, 1994): 9-12.

22. Weingand, "Grounded Theory and Qualitative Methodology," 17-26.

23. Luo, "Effective Training for Chat Reference Personnel."

24. Iowa State University, Strategic Plan 2005-2010. Available online at www.public.iastate. edu/ strategicplan/. [Accessed 28 June 2010].

25. Yun Jeong Park and Curtis J. Bonk, "Is Online Life a Breeze? A Case Study for Promoting Synchronous Learning in a Blended Graduate Course," MERLOT Journal of Online Learning and Teaching 3, no. 3 (2007): 307-23.

26. Stefan Hrastinski, "A Study of Asynchronous and Synchronous E-learning Methods Discovered That Each Supports Different Purposes," EDUCAUSE Quarterly 31, no. 4 (2008): 51-55.

27. Lee Raine, The Role of Libraries in the Digital Age (Washington, D.C.: Pew Research Center, 2008). Slideshow for Texas Libraries Association. Available online at www.pewinternet.org/ Presentations/2008/The-role-of-libraries-in-the-digital-age.aspx. [Accessed 2 April 2010].

28. Peter C. Honebein, "Seven Goals for the Design of Constructivist Learning Environments," in Constructivist Learning Environments: Case Studies in Instructional Design, ed. Brent Wilson (Englewood Cliffs, N.J.: Educational Technology Publishing, 1996), 11-24.

29. Lee Raine, How Libraries Can Survive in the New Media Ecosystem (Washington, D.C.: Pew Research Center, 2009). Slideshow for HELIN Library Consortium, Bryant University. Available online at www.slideshare.net/PewInternet/how-libraries-can-survive-in-the-new-media-ecosystem. [Accessed 2 April 2010]. 


\section{"An investment in knowledge pays the best interest."}

- Benjamin Franklin

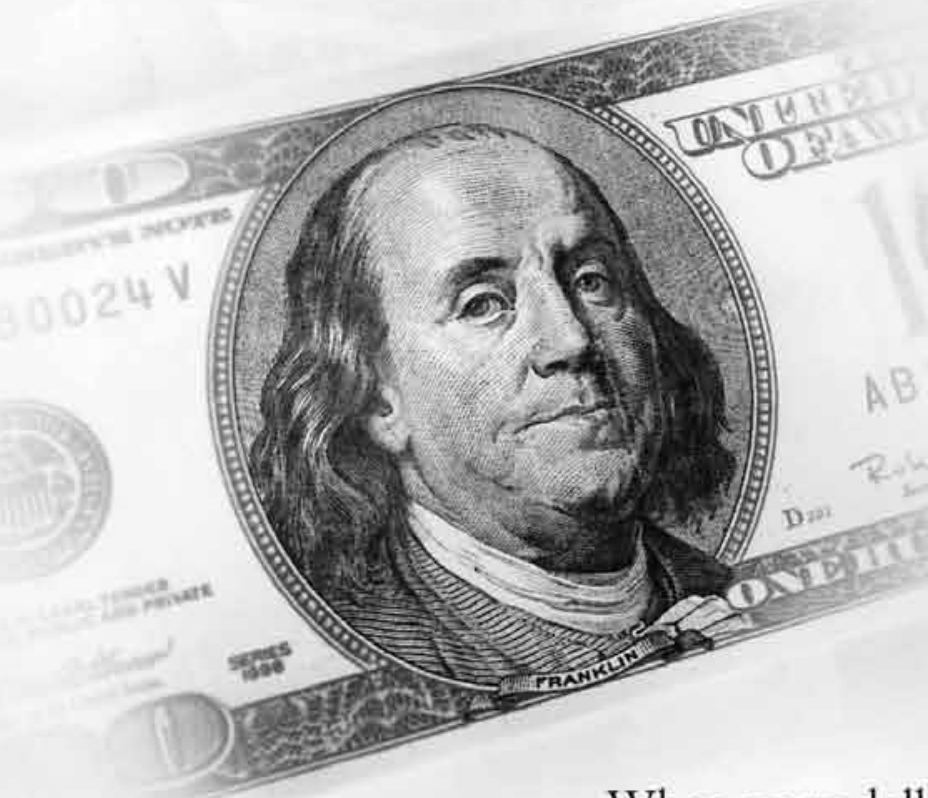

When every dollar counts, get the most out of your budget with Choice Reviews Online.

The perfect companion to a CHOICE print subscription:

- Access to over 145,000 CHOICE reviews

- Download, print or e-mail search results

- Ability to create a customized profile

- Create, save and e-mail lists

- Search all CHOICE content

- View exclusive online material

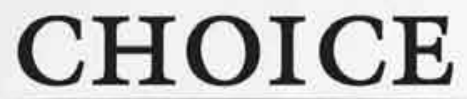

R E V I E W S O N L I N E

To learn more about Choice Reviews Online, visit us at the ALA Annual Conference, booth $\# 1535$, in New Orleans, LA. June 24 - 27, 2011.
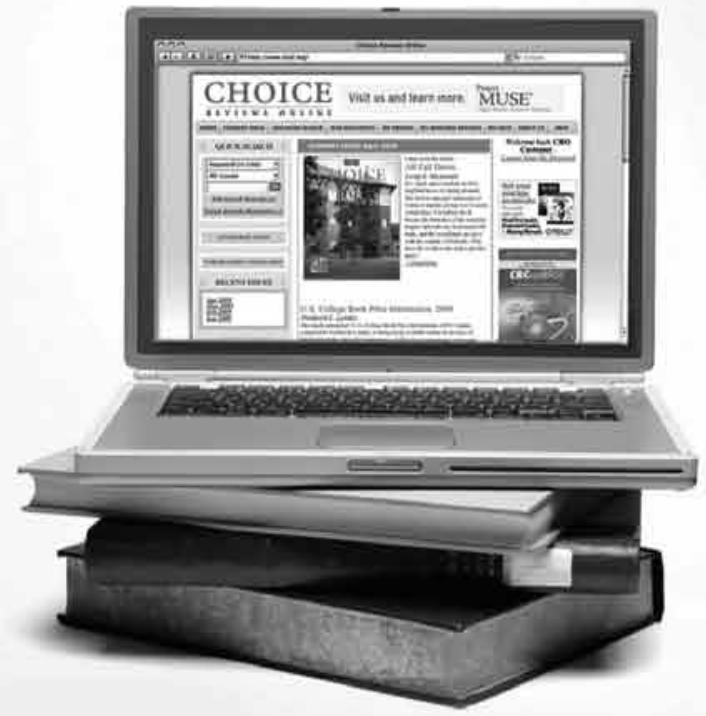